\title{
Perception of pollution and arsenic in hair of indigenous living near a ferronickel open-pit mine (Córdoba, Colombia): Public health case report
}

\author{
Percepción de la contaminación y arsénico en cabello de indigenas \\ viviendo cerca de una mina a cielo abierto de ferroniquel \\ (Córdoba, Colombia): reporte de caso en salud pública
}

Alvaro J Idrovo ${ }^{1}$, Carolina Rivero-Rubio ${ }^{1}$, Claudia Amaya-Castellanos ${ }^{1}$

Suggested citation: Idrovo AJ, Rivero Rubio C, Amaya Castellanos C. Perception of pollution and arsenic in hair of indigenous living near a ferronickel open-pit mine (Córdoba, Colombia): Public health case report. Rev Univ Ind Santander Salud. 2017; 49(1): 115-123. DOI: http://dx.doi.org/10.18273/revsal.v49n1-2017011 @c) (i)

\begin{abstract}
Introduction: Indigenous Zenu residents living near the Cerro Matoso ferronickel mine (Montelibano, Cordoba, Colombia) have complained for many years about adverse health effects. Objective: To explore the perception of sources of pollution, adverse health effects and arsenic levels in the hair of residents near the mine in 2015. Case presentation: Two nominal grouping sessions were conducted (with men and women, separately). The skin of 15 individuals was examined for spots suggestive of hydroarsenicism. Seven hair samples were collected from women and sent to the Centre de Toxicologie du Québec for analysis with inductively coupled plasma mass spectrometry. The proximal, medium and distal segments of the hair were evaluated $(n=21)$. The participants identified the ferronickel mine as the main source of pollution in the region. The exposure pathways they reported correspond to those recognized by environmental health for $\mathrm{NiO}$ and arsenic. The perceived adverse effects from the pollution are consistent with what can be expected when $\mathrm{NiO}$ and arsenic are present. The arsenic concentrations in hair ranged from 0.011 to $0.26 \mu \mathrm{g} / \mathrm{g}$. The highest occurred roughly three years earlier in a girl who was 9 years old at that time. Conclusions: Exposure to arsenic near the ferronickel mine was confirmed, in addition to NiO, mercury and other metals. Future studies could explore the occurrence of adverse effects from arsenic, such as cancer, dermatosis, high blood pressure and reproductive and cardiovascular disorders.
\end{abstract}

Keywords: Arsenic, environmental pollution, mercury, mining, nickel monoxide, qualitative study, toxicology (MeSH).

\section{RESUMEN}

Introducción: Desde hace varios años indígenas de la comunidad Zenú residentes alrededor de la mina de ferroníquel "Cerro Matoso" (Montelibano, Córdoba, Colombia), se quejan de efectos adversos en la salud. Objetivo: Explorar la percepción sobre fuentes de polución, efectos adversos en salud y niveles de arsénico en cabello en individuos

1. Universidad Industrial de Santander. Bucaramanga, Colombia.

Correspondence: Alvaro Javier Idrovo, Dirección: Carrera 32 No. 29-31. Bucaramanga, Santander, Colombia. E-mail: idrovoaj@yahoo.com. mx. Phone number: +7 6344000 ext. 3195

AJI is editor of Salud UIS. During the evaluation process of this article, he did not become part of the committee that made decisions about the review process, and did not know the reviewers. This sought to ensure transparency in the editorial process.

Received: 09/06/2016

Approved: $31 / 01 / 2017$

Publicado Online: 2/02/2017 
residentes cerca de la mina en 2015. Presentación del caso: Se realizaron dos sesiones de grupos nominales (con hombres y mujeres aisladamente). Se revisó la piel de 15 individuos buscando manchas en la piel sugerentes de hidroarsenicismo. Se recolectaron siete muestras de cabello de mujeres, que fueron enviadas para análisis mediante espectrometría de masas con plasma de acoplamiento inductivo en The Centre de Toxicologie du Québec. Se evaluaron los segmentos proximal, medio y distal de cada cabello $(n=21)$. Los participantes identificaron la mina de ferroníquel como la principal fuente de contaminación en la región. Las vías de exposición reportadas corresponden a vías reconocidas en salud ambiental para $\mathrm{NiO}$ y arsénico. Los efectos adversos que se perciben relacionados con la contaminación pueden ser esperados cuando existe $\mathrm{NiO}$ y arsénico. Las concentraciones de arsénico en cabello variaron entre 0.011 y $0.26 \mu \mathrm{g} / \mathrm{g}$. La mayor ocurrió hace tres años aproximadamente en una niña que en ese tiempo tenía 9 años. Conclusiones: Se confirma la exposición a arsénico en los alrededores de la mina de ferroníquel, que se suma a la de NiO, mercurio y otros metales. Futuros estudios podrán explorar la ocurrencia de efectos adversos del arsénico como cáncer, dermatosis, hipertensión arterial y trastornos reproductivos y cardiovasculares.

Palabras clave: arsénico, contaminación ambiental, minería, estudio cualitativo, toxicología (DeCs).

\section{INTRODUCTION}

The indigenous Zenu residents living near one of the largest open-pit ferronickel mines (Montelibano, Córdoba, Colombia) in the world have complained for many years about health problems related with environmental pollution originated by the Cerro Matoso mine. This mine was discovered in the early 1950s, and mining and metallurgy processes began in 1982. The mine is currently controlled by the multinational BHP Billiton mining company. The indigenous residents reported an increase in the occurrence of neoplasms and reproductive, dermatological, ocular and respiratory problems, primarily. Unfortunately, this situation has not been adequately studied because of the early stage in the development of environmental health in Colombia as well as problems with the safety of researchers from the presence of guerrilla and paramilitary groups in the region. In this context, the indigenous community requested help from the Public Health Department of the Universidad Industrial de Santander (UIS) to study the situation.

Considering that waste is one of the main pollutants from mining processes, a study was found in the literature search that reported the presence of $\mathrm{Fe}_{2} \mathrm{O}_{3}$ (iron oxide), $\mathrm{NiO}$ (nickel monoxide) and other oxides among the solid waste material (scum) generated by the ferronickel mine $^{1}$. It is important to remember that the International Agency for Research on Cancer has classified nickel compounds as carcinogenic (Group 1)2. In addition, high levels of $\mathrm{Hg}$ in blood and the presence of $\mathrm{Cd}, \mathrm{Cu}$, $\mathrm{Zn}$ and $\mathrm{Pb}$ in residents in the region have been reported $\mathrm{d}^{3}$, and a study that measured $\mathrm{Hg}, \mathrm{Cu}, \mathrm{Cd}, \mathrm{Pb}, \mathrm{Ni}$ and $\mathrm{Zn}$ in samples of atmospheric deposits identified the presence of $\mathrm{Ni}$ and $\mathrm{Zn}$ metals near the mine ${ }^{4}$, which demonstrated the spread of the mining waste material by the wind. These authors also reported significant levels of $\mathrm{Ni}$ and $\mathrm{Hg}$ in sediments in the San Jorge $\mathrm{River}^{4}$, a region with a high number of substances that are toxic (carcinogenic and non-carcinogenic) to humans and whose joint effects are unknown. In addition to the carcinogenic effects of nickel compounds, it is also important to remember that recent evidence suggests that a synergic action may occur in situations involving accumulated exposure to non-carcinogenic substances, which may increase the occurrence of neoplasms even at very low doses ${ }^{5}$.

Given the social responsibility of the UIS, a decision was made to assign a team of professors with experience in environmental health to explore the situation. The results presented herein represent a preliminary exploration which can serve to guide future studies in the region. This work reflects a public health practice rather than an investigation in the strict sense ${ }^{6}$, and is immersed in one of the principal environmental conflicts responsible for environmental injustice in Colombia ${ }^{7}$. While the activities presented herein do not constitute a formal study, the health significance of the findings motivated us to inform the scientific community in a preliminary manner. In this sense, this work reports the first results of arsenic quantification in hair (possibly related with hydroarsenicism), and community's perceptions on pollution originated in the ferronickel mine, and its relationship with human health.

\section{CASE PRESENTATION}

In October and November 2015, a field visit was conducted in Bocas de Uré, municipality of San Jose de Uré (Figure 1), one of the towns closest to the mine, to obtain preliminary information about the environmental health situation in the region. First, qualitative methods were used to identify the group perception ${ }^{8}$, or interpretation and understanding, of pollution and its effects on human health. Fifteen individuals with skin lesions were examined and, lastly, hair samples were taken to explore the historical exposure to arsenic. These exploratory activities will be described below. 


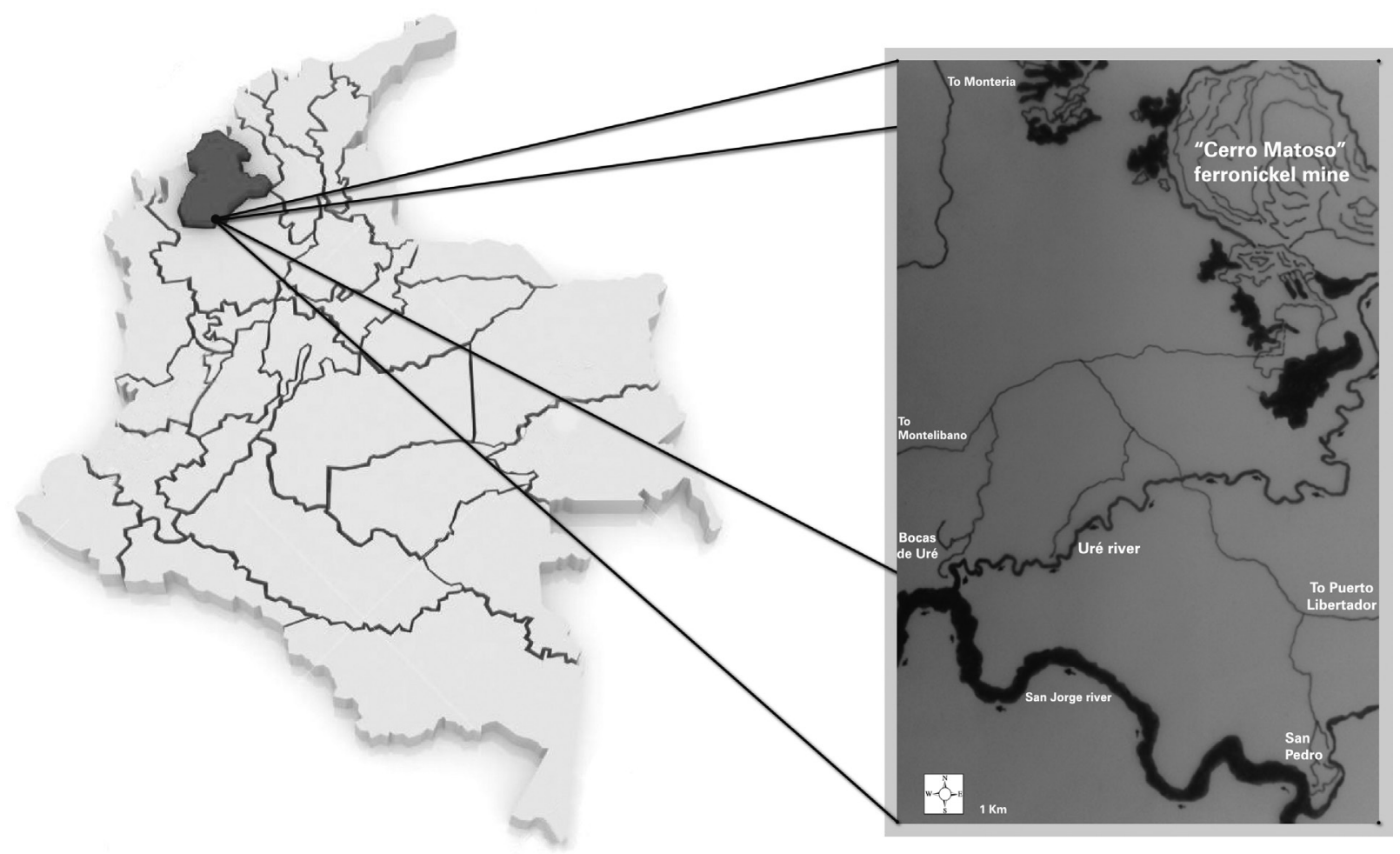

Figure 1. Location of Cerro Matoso ferronickel mine and Bocas de Uré.

Context. San José de Uré is a municipality in Córdoba, Colombia with an extension of $5,161 \mathrm{Km}^{2}$. It has an average temperature of $28^{\circ} \mathrm{C}$ and its municipal head is located 55 meters above sea level. It is the second most distant municipality of the Córdoba's capital ( 149 $\mathrm{Km})$. San José de Uré concentrates $0.64 \%$ of the total population of the department (approximately 10,376 inhabitants for 2011 , of which $\sim 52 \%$ belong to the rural area; it is divided into "corregimientos" of Batatalito, Bocas de Uré, Doradas, Pueblo Flecha, La Cristalina, Versailles and Viera Bajo. The main economic activities are plantation of rubber, rice, chili, yucca, and yam, informal extraction of gold, and the rearing of chickens, pigs and cattle. Houses do not have sewage, and bacteriological and physicochemical quality of the water reported are not safe for human consumption. The coverage for BCG and pentavalent vaccines is low.

In Bocas de Uré is settled a population that belongs to one of the six indigenous cabildos of the Zenú del Alto San Jorge's people. There were 62 families with 147 men and 62 women. Its borders are the Uré creek (east), the canyon of Can river (north), and the San Jorge river (north-west). Inhabitants do not have potable water or sewage system. The economic activities are agriculture (cassava, maize and bananas), fishing, and occasional employment as workers in the Cerro Matoso mine.
Qualitative exploration. Two nominal grouping sessions were conducted with five adult men (39 minutes long) and five adult women (70 minutes long) in Bocas de Uré. Participants were selected by the indigenous community and voluntarily participated after providing informed consent. Occupations of women (31 to 60 years old) were housewife $(n=4)$ or community mother $(n=1)$. Men (27 to 67 years old) worked in fishing and extraction of stone from rivers and streams. Two men reported occasional jobs in the ferronickel mine. Educational level was between illiteracy and full high school. The conversations were recorded on audio. This qualitative technique was chosen since the purpose was not to arrive at consensus but rather identify different perceptions about the study topic ${ }^{9}$, which would help to more fully understand the environmental health situation. To this end, four "a priori" categories were established: i) perception of current conditions in the community, ii) possible sources of pollution, iii) effects of pollution, and iv) solastalgia ${ }^{10}$. The sessions were recorded, transcribed and then analyzed by two investigators (CRR and CIA) with master level studies and experience in qualitative methods. Given the lack of knowledge and uncertainty of the situation under study the methodology was based on grounded theory ${ }^{11}$. 
The five men and five women who participated expressed their perceptions of the source of pollution and its effects on human health. For the participants, the ferronickel mine is clearly the main source of pollution in the region.

"The pollution is from the mine, because of the "scum" it produces (H1) [...] The "scum" is a material that is almost like flying dust; the wind takes care of sprinkling it around, and the "canga" is a solid material." (H3)

"La contaminación es por la mina, por la "escoria" que produce." (H1) [...] La "escoria" es un material casi como un polvillo volátil; la brisa lo encarga de regarlo, y la "canga” es un material sólido." (H3)

According to the participants, this material is directly carried by the wind or through water sources to places where residents are located:

"...then, once a wind kicked up and over there in the region some scum particles fell and everyone looked at each other, and that grease from the scum and people with allergies [...] I would say that it travels a long way ..." (M1)

“... entonces una vez pegó una brisa y ahí en la región cayeron unas partículas de escoria y la gente así se miraba, y eso brillantica de la escoria y gente con alergia [...], yo digo que eso llega muy lejos..." (M1)

"When it rains hard, it seems like blood running down, everything looks red (H3) and it looks like cream on top. It looks like oil, pure grease”. (H2)

"Cuando llueve duro, parece que corriera sangre, se ve toda roja (H3) y se le ve como una nata por encima. Parece que fuera aceite, pura grasa." (H2)

They mentioned that the pollution worsened after the technological changes in the mining-metallurgy process:

"The water used to be taken from the ravine here, you would cook with it, wash with it. (H1) [...] after the last fifteen years since they installed the second line [electric furnace, whereas the first was carbon] it looks more polluted now, you can't take the water for cooking anymore. Before the second line, the smoke could be seen from far away but the scum wasn't seen like it is now". (H2)

"Aqui se cogía el agua de la quebrada, se comía de ahi, se lavaba”. (H1) [...] desde hace 15 años que montaron la segunda línea [horno eléctrico, pues el primero era de carbón] ya se ve más contaminación, ya no se puede coger agua para cocinar. Antes de la segunda línea se veía el humo a lo lejos pero no se veía la escoria como ahora” ( $\mathrm{H} 2)$.

As evidence that the mining process is the source of pollution, they described differences in the Uré River before and after it passes near the mine:

\begin{abstract}
"If you took a look around Uré, you would see how they're joined, from the mine to over there is a change in the water, from the mine to over here there is another [...] We are bathing with that water because they pump it from over there and it doesn't get any kind of treatment". (H2)
\end{abstract}

"Si se pudiera hacer un recorrido al Uré se podría ver el empalme, de la mina hacia allá hay un cambio en el agua, de la mina hacia acá hay otro [...] Con esa agua nos estamos bañando porque la bombean desde allá y no tiene ningún tipo de tratamiento". (H2)

One of the most notable consequences from the pollution is the loss of crops, which can translate into food insecurity for the community:

"...that abundance has ended now, why, because of a lot of pollution now, the rice was lost, the yams, banana, yucca, fish, all of that has been lost. Why? because there is so much pollution".

“...ya esa abundancia se acabó, por qué, porque ya la mucha contaminación, el arroz se perdió, el ñame, el plátano, la yuca, el pescado, todo eso se ha perdido, ¿por qué?, por mucha contaminación que hay". (M2)

The community mentioned that the residents in the region and surrounding areas recognize adverse health effects from the mine. This is so obvious that just living in the region is associated with stigmatization:

"... a boy that was with her said to me, Where are you from? From Montelibano. "You are contaminated." It made me so sad, a disappointment. Because people ask, Where are you from? From Montelibano, and right away, Contaminated!" (H2)

“... un muchacho que iba con ella me dijo ¿y tú de dónde eres? De Montelibano "tú estás contaminado”. Me dio una tristeza, una decepción. Porque la gente pregunta ¿tú de dónde vienes? De Montelibano, y de una vez, ¡contaminado!” (H2)

Respiratory and eye problems as well as skin lesions are frequent among the members of the community. Respiratory problems are associated with the dust that 
comes from the mine, and the skin problems from contact with the water:

"They [referring to the doctors] say that the breathing problem is from cooking with logs, but that's not true because we all cook with logs and people have died because it's just their time, but many don't cook with wood anymore." (H4)

"Ellos [refiriéndose a los médicos] dicen que el problema de respiración es porque cocinan con la leña, pero eso no es cierto porque todos cocinamos con leña y la gente ha muerto porque le toca, pero muchos ya no cocinan con leña." (H4)

"The kids here always have a lot of colds and with choking, because of the pollution". (M6)

"Los niños aqui mantienen con mucha gripa y con asfixia, por la contaminación.” (M6)

"Burning in the eyes, burning. In the morning, this little girl, when we come here in the morning from the farm her eyes get red, red by the time we get to school, her little eyes stay like that, she says they sting”. (M2)

"En los ojos un ardor, un ardor. En la mañana esta niña cuando venimos en la mañana de la finca para acá se le ponen los ojos rojos, rojos al llegar al colegio, mantiene los ojitos así, ella dice que le pican." (M2)

"I have a little 5 year-old girl whose whole little body is like that with spots, I just started to wash her with the water from the ravine and it got like that, spotted means that parts are white like that, the back, all over, like a cloth rag”. (M5)

"Tengo una niñita de 5 años que ella me tiene todo el cuerpecito lo tiene así saraviado, apenas la comencé a bañar con el agua de la quebrada se le puso así, saraviada quiere decir que la tiene por partes blancas así, la espalda, toda, como con paño." (M5)

They also mentioned cases of heart disease and the death of young people, including former workers at the ferronickel mine:

"I had a workmate who had heart problems, it ended up rupturing, they had to put in a pacemaker, and he is now working in another position because they had to get him out of where he was working. Yes it's because of the pollution, there were two, one died but this one was saved. The other died of the same thing, the heart". (H2)

"Yo tenía un compañero que tenía problemas del corazón, le apareció perforado, le tuvieron que poner un marcapasos, y actualmente está trabajando en otro puesto porque tuvieron que sacarlo de donde estaba trabajando. Si es por la contaminación, eran dos, uno murió pero este se salvó. El otro murió de lo mismo, del corazón” (H2).

"My husband was a healthy person and he died young”. (M2)

"Mi esposo era una persona alentada y murió joven.” (M2)

Examination of skin and quantification of arsenic in hair. Fifteen individuals who arrived at the location where the nominal grouping sessions were performed were observed to have skin lesions (hyper- or hypopigmentation). The two physicians on the team (CRR and AJI) examined the lesions present on the individuals. Since the skin lesions were repeatedly mentioned during the interviews and the nominal groups, it was decided to collected hair samples from some of the women in order to measure arsenic. Men had more skin lesions but their hair length were very short to explore large exposure windows (months or years before). This was aimed at exploring the possibility of hydroarsenicism in the region given the presence of compatible skin lesions ${ }^{12}$. This decision prevented the men from participating even though more skin lesions appeared among them.

Seven hair samples were voluntarily taken from women who had always lived in the region, and were sent to the Centre de Toxicologie du Québec of the Institut National de Santé Publique in Québec for analysis, where arsenic was quantified using inductively coupled plasma mass spectrometry. The physicians ascertained about some potential occupational and environmental sources of exposure. None of the participants had a known source of arsenic exposure. However, in the specialized literature mines are potential sources of arsenic.

Three $2 \mathrm{~cm}$ segments of each sample were analyzed: the segment most proximal to the scalp, the most distal segment available and a middle segment. This made it possible to obtain exposure data from different time frames, considering a hair growth of approximately 10 $\mathrm{mm} / \mathrm{month}^{13,14}$. Thus the analysis explored exposure over the prior two months, one year prior and the period corresponding to the maximum hair length. Not destroyed hair during the analysis is stored by the toxicological laboratory in Canada.

The results show the concentrations of arsenic in hair ranging from 0.011 to $0.26 \mu \mathrm{g} / \mathrm{g}$ for the different time 
frames explored (Figure 2). The case of a 12 yearold girl who had the highest values is particularly noteworthy. This was found in the $35-37 \mathrm{~cm}$ segment which suggests that high exposure occurred approximately three years earlier. There was no specific sources of arsenic exposure identified in this case. She was student (secondary) with regular self-report health status; the water for human consumption in her house was obtained from a pipe without treatment. Arsenic was detected in all the other cases, which suggests that exposure to low concentrations is ubiquitous, although the possibility of specific cases of high exposure is not dismissed. Unfortunately, this exploration could not identify the potential source of exposure.

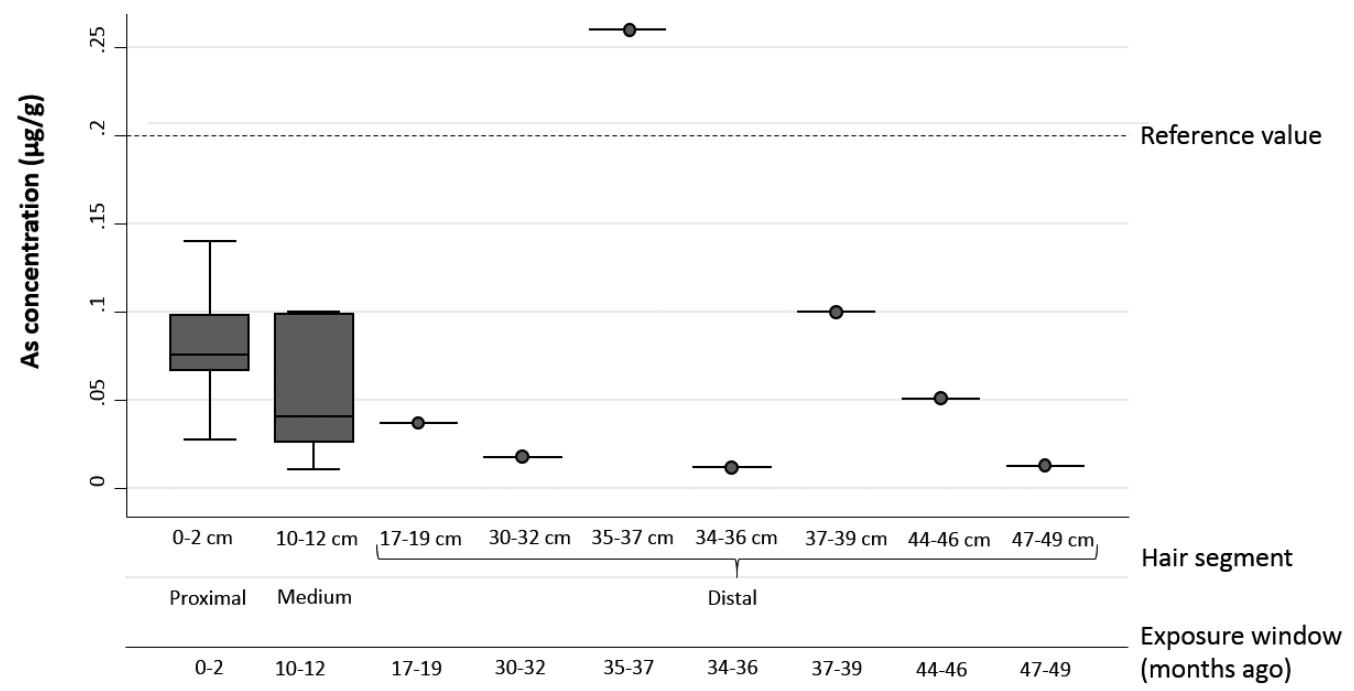

Figure 2. Concentration of arsenic in hair $(\mu \mathrm{g} / \mathrm{g})^{*}$ among indigenous women living near the Cerro Matoso ferronickel mine $(n=21)$.

* the reference value is from the Centre de Toxicologie du Québec, Institut National de Santé Publique, Quebec, Canada.

\section{ETHICAL CONSIDERATIONS}

Since this work was the consequence of a community request and was not a formal scientific study, there was not ethics committee approval. However, researchers met all national and international standards required in health studies with indigenous communities including children. Volunteers were informed of all activities undertaken, especially those related with examination of skin and quantification of arsenic in hair. This was pleasing to the community because this knowledge is a great benefit and it helps to resolve doubts about the diseases that affect several individuals. All participants signed an informed consent. Additionally, in the case of children their affirmative agreements with the clinical examination were obtained directly from each child.

\section{DISCUSSION}

For the indigenous, the Cerro Matoso ferronickel mine is clearly the main source of environmental pollution in the region. This is not odd given the large area occupied by the mine and its close proximity to the population. The indigenous community is clearly inside the mine's direct area of influence. In addition, the discourse of the participants is congruent with exposure pathways that are known to occur for nickel, iron and arsenic, as well as other metals. In terms of nickel, the stories about winds transporting mining residues to surrounding areas are consistent with the findings of a previous environmental study ${ }^{4}$. The presence of water sources that pass near the mine, their excessive sedimentation and changes in the color of the water are indications of the movement of metals.

Previous studies in the region and the informants indicate the existence of other sources of pollution, such as carbon and gold mines which are associated with the presence of other metals ${ }^{3,4}$. This strengthens the premise that the arsenic that is geologically present in the region ${ }^{15}$ can be transported by mining activities and reach humans through water used for human consumption and foods such as vegetables, fish and seafood, primarily.

This study's findings about arsenic merit special attention. Rather than attempting to associate its presence in the hair of women with health effects, which could be studied by future investigations, these results should be understood as an exploration of different arsenic exposure 
time frames. The data clearly indicate the presence of the metalloid in concentrations similar to those reported in areas where mines exist ${ }^{16-18}$. The case that exceeds the reference value is an indication of the existence of populations with a higher degree of vulnerability, or where episodes have occurred in which arsenic increased due to accidents or disasters in mining areas, such as in Spain $^{19}$ and more recently in Mexico ${ }^{20}$ and Brazil ${ }^{21}$.

The exploration also showed that some of the indigenous residents (particularly men) had skin lesions characterized by hyper- or hypo-pigmentation suggestive of hydroarsenicism. This type of lesion is similar to those reported in other regions in the world where low levels of arsenic are found in water for human consumption ${ }^{12}$. It is important to remember that adverse reproductive events ${ }^{22,23}$, high blood pressure and heart disease ${ }^{24}$ have been seen even with low arsenic concentrations. It is also important to note that these diseases are among those indicated by the indigenous community as present and they associate them with the ferronickel mine.

These findings should be interpreted in accordance with the limitations of the approaches used. Given the exploratory nature of this public health practice, the results are not representative nor can they be generalized to the population residing in the region. Complex environmental and environmental health studies are required in order to more fully understand the problem. Nevertheless, the presence of arsenic may create a health emergency of unforeseeable dimensions which, until now, has been hidden from the society. The effects may act synergically with other carcinogens, such as the $\mathrm{NiO}$ present in the region, as well as with other noncarcinogenic metals. A robust active surveillance system could be in the region to identify possible adverse health effects related with environmental pollution.

This is a clear example in which environmental impact studies of mining activities have not been able to evaluate the potential effects of mining processes on human health. The authorities urgently need to modify the lax and permissive regulations that excessively favor the mining sector by adopting regulations centered on valuing humans ${ }^{25}$, and which enable performing a real cost-benefit evaluation. A recent study in a region of Colombia where a carbon mine is located indicates that the socio-environmental costs, and especially those involving disease, can exceed the economic benefits of extracting the mineral ${ }^{26}$. According to the available data, that situation is not as serious for environmental health as the one described by the present work.
As a public health measure, unpolluted potable water needs to be immediately supplied to the population, and an aqueduct needs to be built to ensure the treatment and supply of water having excellent quality. This is undoubtedly within the scope of the actions that can be taken by the multinational that manages the mine, in addition to others that have been implemented in other regions of the world ${ }^{27}$. The national health authorities were duly informed of this situation. Continuing these conditions where communities continue to experience high social vulnerability after more than 30 years of mining exploitation, and the mine's generation of large profits would unnecessarily perpetuate environmental injustice and social inequity.

Community leaders were informed of findings of this exploration, and an official report was delivered to the community. It could be used to support complaints submitted to government institutions and courts. Clinical decisions were not taken because results are related exclusively on exposures, and a formal study is needed to explore the causal relationship between mining wastes and adverse outcomes. Currently, some researchers from different universities are seeking funding to realize a big study in the region, and the Colombian Institute of Legal Medicine and Forensic Sciences did a study following judicial orders. These findings are not public. Dissemination of these results to the scientific community is a researcher's commitment to visualize this hidden problem.

\section{ACKNOWLEDGEMENTS}

Thank you to the indigenous Zenú community for their collaboration during the fieldwork. Measurements of arsenic in hair were performed by Centre de Toxicologie du Québec, Institut National de Santé Publique, Quebec, Canada.

The study was supported by the Public Health Department, School of Medicine, Universidad Industrial de Santander, and the researchers' own resources.

\section{CONFLICTS OF INTEREST}

The authors declare that there are no conflicts of interest.

\section{REFERENCES}

1. Hernández Y, Carriazo JG, Almanza O. Characterization by XRD and electron paramagnetic resonance (EPR) of waste materials from "Cerro Matoso" mine (Colombia). Mater Charact. 2006; 
57: 44-49. DOI: 10.1016/j.matchar.2005.12.003.

2. IARC Working Group. Nickel and nickel compounds. In: arsenic, metals, fibres, and dusts Volume $100 \mathrm{C}$. A review of human carcinogens. IARC monographs on the evaluation of carcinogenic risks to humans. Lyon, France: International Agency for Research on Cancer; 2012: 169-218.

3. Madrid GL, Gracia Herrera LC, Marrugo Negrete JL, Urango Cardenas ID. Genotoxicidad de metales pesados $(\mathrm{Hg}, \mathrm{Zn}, \mathrm{Cu}, \mathrm{Pb}$ y $\mathrm{Cd})$ asociado a explotaciones mineras en pobladores de la cuenca del río San Jorge del departamento de Córdoba, Colombia. Rev Asoc Col Cienc. 2011; 23: 103-111.

4. Marrugo-Negrete JL, Urango-Cardenas ID, Burgos Núñez SM, Díez S. Atmospheric deposition of heavy metals in the mining area of the San Jorge river basin, Colombia. Air Qual Atmos Health. 2014; 7(4): 577-588. DOI: 10.1007/s11869-0140278-3.

5. Goodson WH 3rd, Lowe L, Carpenter DO, Gilbertson M, Manaf Ali A, Lopez de Cerain Salsamendi A, et al. Assessing the carcinogenic potential of low-dose exposures to chemical mixtures in the environment: the challenge ahead. Carcinogenesis. 2015; 36(Suppl 1): S254-296. DOI: 10.1093/carcin/bgv039.

6. Amoroso PJ, Middaugh JP. Research vs. public health practice: when does a study require IRB review?. Prev Med. 2003; 36(2): 250-253.

7. Pérez-Rincón MA. Injusticias ambientales en Colombia: estadísticas y análisis para 95 casos. Amb Sosten 2014; 4: 65-78.

8. Blanco-Becerra LC, Pinzón-Flórez CE, Idrovo AJ. Estudios ecológicos en salud ambiental: más allá de la epidemiología. Biomédica. 2015; 35(supl.2): 191-206. DOI: http://dx.doi.org/10.7705/biomedica. v35i0.2819.

9. Langford BE, Schoenfeld G, Izzo G. Nominal grouping sessions vs focus groups. Qual Market Res. 2002; 5: 58-70. DOI: http://dx.doi. org/10.1108/13522750210414517.

10. Albrecht G, Sartore GM, Connor L, Higginbotham N, Freeman S, Kelly B, et al. Solastalgia: the distress caused by environmental change. Australas Psychiatry. 2007; 15(Suppl 1): S95-98. DOI: 10.1080/10398560701701288.

11. Glaser BG, Strauss AL. The discovery of grounded theory: Strategies for qualitative research. New York: Aldine; 1967.

12. Karagas MR, Gossai A, Pierce B, Ahsan H. Drinking water arsenic contamination, skin lesions, and malignancies: a systematic review of the global evidence. Curr Environ Health Rep. 2015; 2(1): 52-
68. DOI: $10.1007 / \mathrm{s} 40572-014-0040-\mathrm{x}$.

13. Kintz P. Value of hair analysis in postmortem toxicology. Forensic Sci Int. 2004; 142(2-3): $127-$ 134. DOI: 10.1016/j.forsciint.2004.02.027.

14. Sen J. Human hair in personal identification and documenting drug and substance abuse. Anthropologist. 2010; 12(1): 47-58.

15. Alonso DL, Latorre S, Castillo E, Brandão PF. Environmental occurrence of arsenic in Colombia: a review. Environ Pollut. 2014; 186: 272-281. DOI: 10.1016/j.envpol.2013.12.009.

16. Bidone E, Castilhos Z, Cesar R, Santos MC, Sierpe R, Ferreira M. Hydrogeochemistry of arsenic pollution in watersheds influenced by gold mining activities in Paracatu (Minas Gerais State, Brazil). Environ Sci Pollut Res Int. (in press). DOI: 10.1007/ s11356-016-6089-3.

17. Romero-Freire A, García Fernández I, Simón Torres M, Martínez Garzón FJ, Martín Peinado FJ. Long-term toxicity assessment of soils in a recovered area affected by a mining spill. Environ Pollut. 2016; 208(Pt B): 553-561. DOI: 10.1016/j. envpol.2015.10.029.

18. Álvarez-Ayuso E, Abad-Valle P, Murciego A, VillarAlonso P. Arsenic distribution in soils and rye plants of a cropland located in an abandoned mining area. Sci Total Environ. 2016; 542(Pt.A): 238-246. DOI: 10.1016/j.scitotenv.2015.10.054.

19. Grimalt JO, Ferrer M, Macpherson E. The mine tailing accident in Aznalcollar. Sci Total Environ. 1999; 242(1-3): 3-11.

20. Díaz-Caravantes RE, Duarte-Tagles H, DurazoGálvez FM. Amenazas para la salud en el Río Sonora: análisis exploratorio de la calidad del agua reportada en la base de datos oficial de México. Rev Univ Ind Santander Salud. 2016; 48(1): 91-96. DOI: http://dx.doi.org/10.18273/revsal.v48n1-2016010.

21. Lambertz M, Dergam JA. Mining disaster: Huge species impact. Nature. 2015; 528(7580): 39. DOI: $10.1038 / 528039 b$.

22. Claus Henn B, Ettinger AS, Hopkins MR, Jim R, Amarasiriwardena C, Christiani DC, et al. Prenatal arsenic exposure and birth outcomes among a population residing near a mining-related superfund site. Environ Health Perspect. 2016; 124(8): 13081315. DOI: 10.1289/ehp.1510070.

23. Quansah R, Armah FA, Essumang DK, Luginaah I, Clarke E, Marfoh K, et al. Association of arsenic with adverse pregnancy outcomes/infant mortality: a systematic review and meta-analysis. Environ Health Perspect. 2015; 123(5): 412-421. DOI: 10.1289/ehp.1307894.

24. Jiang J, Liu M, Parvez F, Wang B, Wu F, Eunus 
$\mathrm{M}$, et al. Association between arsenic exposure from drinking water and longitudinal change in blood pressure among HEALS cohort participants. Environ Health Perspect. 2015; 123(8): 80-12. DOI: 10.1289/ehp. 1409004.

25. Idrovo AJ. Desastres mineros por vertimientos químicos son un peligro para la salud humana [comentario editorial]. Rev Univ Ind Santander Salud. 2016; 48(1): 119-120.

26. Cardoso A. Behind the life cycle of coal: Socioenvironmental liabilities of coal mining in Cesar, Colombia. Ecol Econ. 2015; 120: 71-82. DOI: 10.1016/j.ecolecon.2015.10.004.

27. Mayes R. A social licence to operate: corporate social responsibility, local communities and the constitution of global production networks. Global Networks 2015; s1: S109-28. DOI: 10.1111/ glob.12090. 